\title{
Acute exposure of symptomatic steelworkers to sulphur dioxide and carbon dust: effects on mucociliary transport, pulmonary function, and bronchial reactivity
}

\author{
R K WOLFF, ${ }^{*}$ G OBMINSKI, AND M T NEWHOUSE \\ From McMaster University and St Joseph's Hospital, Hamilton, Ontario, Canada
}

ABSTRACT Nine steel workers participated in controlled exposures to sulphur dioxide alone and sulphur dioxide plus carbon dust ( $5 \mathrm{ppm}$ and $10 \mathrm{mg} / \mathrm{m}^{3}$, respectively). All were experiencing work related respiratory difficulties. Bronchial clearance was measured using radioaerosol inhalations and external detection. Results were variable and no statistically significant changes were observed. One asthmatic showed a complete cessation of clearance during exposure to sulphur dioxide and carbon dust. Bronchial reactivity was found to be significantly raised after exposure to sulphur dioxide but equivocal results were found after exposure to sulphur dioxide and carbon dust. Pronounced changes in pulmonary function were seen only in the two asthmatic subjects. They could not tolerate the levels, indicating that these threshold limit values are too high, at least for these individuals who showed much greater sensitivity to the pollutants than the others.

Most previous work on experimental human exposures to sulphur dioxide $\left(\mathrm{SO}_{2}\right)$ or carbon dust has involved healthy volunteers. ${ }^{1-4}$ Nevertheless, since these data relate to industrial threshold limit values (TLVs) it seemed advisable to obtain additional data on exposures from workers who encounter these agents in their everyday environment. With this in mind we chose to study not young healthy volunteers but workers who were experiencing some respiratory difficulties at work. The question was whether these subjects showed responses in mucociliary clearance and pulmonary function similar to the group of healthy volunteers previously studied $^{2}$ or whether they exhibited any altered sensitivity. These subjects were exposed to TLV-short term exposure limit levels of $\mathrm{SO}_{2}$ alone and $\mathrm{SO}_{2}$ and carbon dust ( $5 \mathrm{ppm} \mathrm{SO}{ }_{2}$ and $10 \mathrm{mg} / \mathrm{m}^{3}$ carbon dust) in acute exposures of 2.5 hours duration. Changes in pulmonary function, mucous clearance, and bronchial reactivity were measured. These measure-

Received 5 June 1983

Accepted 13 September 1983 ments were chosen since alterations have been observed in all after exposure to various pollutants. Combinations of measurements have rarely been made in the same subjects, and we wished to see if there were correlations between changes in different measurements and if any one measurement was more sensitive than the others.

\section{Materials and methods}

SUBJECTS

Nine individuals from a group of steelworkers who were outpatients at St Joseph's Hospital volunteered for the study. All were employed at the major steel mills in Hamilton and suffered from respiratory difficulties (shortness of breath, pronounced cough or wheeze, or both) which they reported occurred primarily at work. Table 1 shows the age, height and pulmonary function data of the subjects. Table 2 gives a detailed profile of the subjects. Most had never smoked and none was a smoker at the time of the study. Subjects 1-7 felt healthy, with only minor respiratory problems when away from work and 
Table 1 Baseline pulmonary function measurements

\begin{tabular}{|c|c|c|c|c|c|c|c|c|c|c|}
\hline \multirow[t]{2}{*}{ Subject } & \multirow[t]{2}{*}{ Height $(\mathrm{cm})$} & \multirow[t]{2}{*}{ Age } & \multicolumn{2}{|l|}{$F E V_{1}$} & \multicolumn{2}{|l|}{$F V C$} & \multicolumn{2}{|c|}{$F E F_{75-25}$} & \multicolumn{2}{|c|}{$T L C$} \\
\hline & & & Pred & $O b s$ & Pred & Obs & Pred & $O b s$ & Pred & Obs \\
\hline $\begin{array}{l}1 \\
2 \\
3 \\
4 \\
5 \\
6 \\
7 \\
7 \\
8 \\
9\end{array}$ & $\begin{array}{l}167 \\
170 \\
163 \\
153 \\
160 \\
178 \\
168 \\
162 \\
187\end{array}$ & $\begin{array}{l}45 \\
44 \\
44 \\
62 \\
46 \\
45 \\
55 \\
26 \\
28\end{array}$ & $\begin{array}{l}3.05 \\
3.30 \\
3.15 \\
2.25 \\
2.70 \\
3.40 \\
2.80 \\
3.65 \\
4 \cdot 10\end{array}$ & $\begin{array}{l}3.60 \\
3.40 \\
3.85 \\
1.80 \\
1.90 \\
2.40 \\
2.70 \\
2.47 \\
2.80\end{array}$ & $\begin{array}{l}4 \cdot 05 \\
4 \cdot 35 \\
4 \cdot 02 \\
2.73 \\
3.40 \\
4 \cdot 68 \\
3.74 \\
4 \cdot 30 \\
5 \cdot 60\end{array}$ & $\begin{array}{l}4.70 \\
4.70 \\
4 \cdot 50 \\
3.31 \\
3.06 \\
3.90 \\
3.90 \\
4.07 \\
5.35\end{array}$ & $\begin{array}{l}3 \cdot 60 \\
3 \cdot 80 \\
3 \cdot 70 \\
2.70 \\
3 \cdot 20 \\
3 \cdot 60 \\
3 \cdot 00 \\
4 \cdot 4 \\
4 \cdot 5\end{array}$ & $\begin{array}{l}3.30 \\
2.75 \\
4.95 \\
1.35 \\
1.25 \\
1.60 \\
2.10 \\
1.19 \\
1.09\end{array}$ & $\begin{array}{l}6 \cdot 06 \\
6 \cdot 21 \\
5 \cdot 74 \\
4 \cdot 50 \\
5 \cdot 12 \\
7 \cdot 00 \\
5 \cdot 91\end{array}$ & $\begin{array}{l}5 \cdot 66 \\
6 \cdot 43 \\
7 \cdot 82 \\
5 \cdot 51 \\
5 \cdot 62 \\
8 \cdot 79 \\
6 \cdot 65 \\
* \\
*\end{array}$ \\
\hline
\end{tabular}

*Not available.

they could be described as having "industrial bronchitis" of varying degrees. Smoking probably played a large part in the symptomology of subjects 5,6 , and 8 ; subjects 8 and 9 were asthmatic and had non-work related wheezing episodes.

Informed consent was obtained from each individual after the procedures had been carefully and completely explained to them.

\section{AEROSOL DEPOSITION AND CLEARANCE \\ MEASUREMENTS}

The radioactive test aerosol used to measure clearance was ultrasonically generated from a solution of ${ }^{99 \mathrm{~m}} \mathrm{Tc}$-albumin in physiological saline. The activity aerodynamic mass median diameter was $3 \mu \mathrm{m}$ and $\sigma_{\mathrm{g}} 1 \cdot 6$.

${ }^{\mathrm{g}} \mathrm{A}$ bolus technique described previously' was used to achieve reproducible proximal deposition of aerosol in the lung. In each of the present experiments radioaerosol inhalations were performed before exposure to the pollutants and the effects on mucociliary clearance were determined by measuring the changes in lung retention of the radioactivity during a 2.5 hour period. In each experiment inhalations were conducted under carefully controlled conditions and the subjects took 20 aerosol breaths, each of reproducible volume and flow rate, by mouth.

An Anger scintillation camera was interfaced with a data storage and retrieval system that allowed off line computer data handling. ${ }^{5}$ Measurements of lung retention of activity were made from a $2^{\prime \prime} \times 4^{\prime \prime}$ region (inner zone) over the right lung centred at the carina, a middle zone consisting of a crescent around the inner zone terminating at the mediastinum, and an outer zone, a 1 " crescent around the middle zone. Lung retention was calculated from the sum of activity in all three zones.

\section{EXPOSURES}

Three separate 2.5 hour exposures were carried out for each non-asthmatic individual in the following order on successive weeks:

(1) placebo (clean air),

(2) $5 \mathrm{ppm} \mathrm{SO}$, and

(3) $5 \mathrm{ppm} \mathrm{SO}+10 \mathrm{mg} / \mathrm{m}^{3}$ carbon dust.

Both asthmatics were first exposed to $5 \mathrm{ppm} \mathrm{SO}_{2}$, but because of their reaction at this level they were subsequently exposed to $1 \mathrm{ppm}$. Subject 9 could not be studied with $\mathrm{SO}_{2}+$ carbon dust because he moved from the area before the final study could be completed.

Table 2 Smoking habits, work history, pulmonary function, and diagnosis of subjects

\begin{tabular}{|c|c|c|c|c|}
\hline Subject & Smoking habits & Job (No of years at steel mills & Pulmonary function & Preliminary diagnosis \\
\hline $\begin{array}{l}1 \\
2 \\
3 \\
4\end{array}$ & $\begin{array}{l}\text { Non-smoker } \\
\text { Non-smoker } \\
\text { Non-smoker } \\
\text { Non-smoker }\end{array}$ & $\begin{array}{l}\text { Open hearth (14) } \\
\text { Slag pits (18) } \\
\text { Welder (23) } \\
\text { Welder (28) }\end{array}$ & $\begin{array}{l}\text { Normal } \\
\text { Normal } \\
\text { Normal } \\
\text { FEV, slightly reduced }\end{array}$ & \multirow{2}{*}{$\begin{array}{l}\text { Mild bronchial hyperreactivity } \\
\text { Normal } \\
\text { Mild bronchial hyperreactivity } \\
\text { Minimal airway obstruction, } \\
\text { some hyperinflation } \\
\text { Minimal airway obstruction }\end{array}$} \\
\hline 5 & $\begin{array}{l}\text { Ex-smoker for } 6 \text { years; } \\
\text { 20-pack years previously }\end{array}$ & Open hearth (20) & FEV, slightly reduced & \\
\hline $\begin{array}{l}6 \\
7\end{array}$ & $\begin{array}{l}\text { Ex-smoker } \\
\text { Non-smoker }\end{array}$ & $\begin{array}{l}\text { Basic oxygen furnace (17) } \\
\text { Open hearth ( } 29)\end{array}$ & $\begin{array}{l}\text { FEV, slightly reduced } \\
\text { Normal }\end{array}$ & \multirow{3}{*}{$\begin{array}{l}\text { Minimal airway obstruction } \\
\text { Subacute bronchitis, some } \\
\text { sputum production } \\
\text { Asthmatic ragweed sensitive, } \\
\text { mild chronic bronchitis } \\
\text { Asthmatic }\end{array}$} \\
\hline 8 & $\begin{array}{l}\text { Ex-smoker for } 6 \text { months; } \\
\text { 16-pack years previously }\end{array}$ & $\begin{array}{l}\text { Open hearth basic oxygen } \\
\text { furnace }(6)\end{array}$ & FEV 1 reduced obstructive & \\
\hline 9 & Non-smoker & Open hearth (3) & FEV, reduced & \\
\hline
\end{tabular}


Each exposure was started immediately after inhalation of the radioactive aerosol. Initially there was a half hour rest period. In all experiments there was an exercise period of from 0.5 to 1.0 hour consisting of five sessions lasting four minutes, exercising at $50-60 \%$ of the maximum predicted heart rate. The four minute exercise sessions were separated by two minute rest periods. Subjects were at rest from 1.0 to 2.5 hours. Both placebo and pollutant exposures lasted a total of 2.5 hours and were carried out in a $2.1 \times 1.8 \times 1.2 \mathrm{~m}$ plexiglass chamber that has already been described. ${ }^{1}$ Five $\mathrm{ppm} \mathrm{SO}_{2}$ exposures were achieved as described previously ${ }^{1}$ using a controlled flow rate from a $1 \% \mathrm{SO}_{2}$ compressed gas cylinder.

The carbon dust was generated from a Wright dust feeder having been prepared by ball milling coconut charcoal overnight. In samples taken from the exposure chamber the particle size was $1 \mu \mathrm{m}$ count median diameter. The dust was compressed in a stainless steel feed cylinder at a pressure of 2000 psi, six successive compressions of 10 second duration being used to eliminate rebound of the material. The dust feeder injected the material into the ducting behind the intake fan of the chamber. When generating dust it was necessary to increase the $\mathrm{SO}_{2}$ flow by $20 \%$ above the flow rate when no dust was present to obtain a $5 \mathrm{ppm}$ reading on the $\mathrm{SO}_{2}$ analyser, presumably because some $\mathrm{SO}_{2}$ was adsorbed on to the carbon particles.

In the laboratory air the $\mathrm{SO}_{2}$ concentration was $0.01-0.02 \mathrm{ppm}$, particulates were $<50 \mu \mathrm{g} / \mathrm{m}^{3}$ and the ozone concentration was $<0.01 \mathrm{ppm}$.

The temperature in the chamber was maintained at $22 \pm 1^{\circ} \mathrm{C}$ and the relative humidity at $50 \pm 5 \%$.

Mouth breathing was used in all experiments. To achieve this, the nose was occluded with cotton batting. A small quantity of water was swallowed before each radioactive aerosol retention reading to wash interfering activity from the oesophagus.

Inhaled radioactivity was approximately $50-100$ $\mu \mathrm{Ci}$ per experiment which corresponds to a 1-2 mrad whole body dose.

All measurements of pollutant exposure were compared with control measurements by analysing the retention values at two hours using two tailed paired $t$ tests testing for significance at $\mathrm{p}=0.05$ with the $t$ value scaled for multiple comparisons. ${ }^{6}$

\section{PULMONARY FUNCTION TESTS}

Spirograms were obtained before exposures in each experiment using a spirometer from Vitalograph Medical Instrumentation. Flow volume curves were obtained using a Wedge spirometer. In this way baseline values for vital capacity (VC), one second forced expired volume $\left(\mathrm{FEV}_{1}\right)$, forced expired flow from $75 \%$ to $25 \%$ of VC $\left(\mathrm{FEF}_{75-25}\right)$, maximum flow at $50 \% \mathrm{VC}\left(\dot{\mathrm{V}}_{\max }\right)$ and at $25 \% \mathrm{VC}\left(\dot{\mathrm{V}}_{\max }\right)$ were measured. After exposures were started spirograms and flow-volume curves were taken at $5,10,15,30$, 90,120 , and 150 minutes. The average of the best two values from three efforts were used. For the two asthmatic subjects, spirograms were also taken after each four minute exercise session in the $0.5-1 \cdot 0$ hour period.

\section{BRONCHIAL REACTIVITY MEASUREMENTS}

Airway reactivity to inhaled aerosolised histamine was measured 15 minutes after the end of exposure to pollutant or placebo using the method modified from Cockcroft et al. ${ }^{7}$ Starting with low concentrations $(0.03 \mathrm{mg} / \mathrm{ml})$ ten breaths were taken from the controlled breath nebuliser apparatus (see clearance measurements) and the $\mathrm{FEV}_{1}$ was measured at one, two, three, four, and five minutes after the end of inhalation. If the FEV, fell by more than $20 \%$ from control, or if subjective irritation was too great, the inhalations were stopped. If not the procedure was repeated with double histamine concentrations until a $20 \%$ fall was achieved; the concentration producing this fall was called the threshold concentration. A threshold concentration was determined after the placebo exposure to give a certain percentage fall and then the threshold concentration was administered after each of the other exposures and percentage fall in $\mathrm{FEV}_{1}$ measured each time.

Paired $t$ tests with the $t$ value adjusted for multiple comparisons were used to test each of the pulmonary function measures and the bronchial reactivity measurements for significance at the $p=0.05$ level. Measurements made for experiments entailing exposures to pollutants were compared with measurements at the same time during control experiments.

\section{Results}

PULMONARY FUNCTION

Table 3 shows the changes in $\mathrm{FEV}_{1}, \mathrm{FEF}_{75-25}$, $\dot{\mathrm{V}}_{\max _{50}}$, and $\dot{\mathrm{V}}_{\max _{25}}$. The changes were not dramatic, except for the exposures of subjects 8 and 9, both asthmatics, to $5 \mathrm{ppm} \mathrm{SO}_{2}$. Apart from these responses $\dot{V}_{50}$ and $V_{25}$ decreased in subjects $1,3,4$, and 7 late in the exposure $(2-2 \cdot 5 \mathrm{~h})$.

Subject 8 had a reduction of $25 \%$ in $\mathrm{FEV}_{1}$ after 30 minutes exposure to $5 \mathrm{ppm} \mathrm{SO}_{2}$ at rest and, after four minutes of exercise, a reduction of $60 \%$ from baseline, at which time the exposure was terminated and a bronchodilator administered. Pulmonary function and clearance measurements were continued until the end of the $2.5 \mathrm{~h}$ experiment. This subject was later exposed to $1 \mathrm{ppm} \mathrm{SO}_{2}$ and to $1 \mathrm{ppm} \mathrm{\textrm {SO } _ { 2 }}$ 
Table 3 Pulmonary function values as a percentage of control

\begin{tabular}{|c|c|c|c|c|c|c|c|c|c|c|c|c|c|c|c|c|}
\hline \multirow[t]{2}{*}{ Subject } & \multicolumn{4}{|l|}{$F E \dot{V}_{1}$} & \multicolumn{4}{|c|}{$M M F R$} & \multicolumn{4}{|l|}{$\dot{V}_{30}$} & \multicolumn{4}{|l|}{$\dot{V}_{25}$} \\
\hline & $\underset{E}{\mathrm{SO}_{2}}$ & $L$ & ${ }_{E}^{\mathrm{SO}_{2}}$ & ${ }_{L}^{d u s t}$ & $\underset{E}{\mathrm{SO}_{2}}$ & $L$ & $\begin{array}{l}\mathrm{SO}_{2} \\
\end{array}$ & $\stackrel{d u s t}{L}$ & $\underset{E}{S_{E} O_{2}}$ & $L$ & ${ }_{E}^{S O_{2}}+$ & $\underset{L}{d u s t}$ & $\begin{array}{l}\mathrm{SO}_{2} \\
\mathrm{E}\end{array}$ & $L$ & $\underset{E}{\mathrm{SO}_{2}+}$ & $\stackrel{d u s t}{L}$ \\
\hline $\begin{array}{l}1 \\
2 \\
3 \\
4 \\
5 \\
6 \\
7 \\
8 \\
9 \\
9 \\
\text { Mean }\end{array}$ & $\begin{array}{c}92 \\
100 \\
101 \\
100 \\
89 \\
108 \\
101 \\
41^{*} \\
93^{\dagger} \\
73 \dagger \\
90 \\
\end{array}$ & $\begin{array}{r}95 \\
101 \\
99 \\
101 \\
86 \\
115 \\
98 \\
79 \\
90 \\
100 \\
96 \\
\end{array}$ & $\begin{array}{r}103 \\
97 \\
97 \\
104 \\
83 \\
102 \\
97 \\
87 \\
\\
96\end{array}$ & $\begin{array}{r}84 \\
97 \\
99 \\
96 \\
83 \\
101 \\
91 \\
85 \\
92\end{array}$ & $\begin{array}{c}74 \\
100 \\
100 \\
102 \\
79 \\
108 \\
103 \\
37^{*} \\
91 \\
64^{*} \\
86\end{array}$ & $\begin{array}{c}92 \\
94 \\
98 \\
107 \\
80 \\
115 \\
101 \\
66^{*} \\
97 \\
99 \\
85 \\
\end{array}$ & $\begin{array}{r}111 \\
93 \\
93 \\
108 \\
76 \\
99 \\
103 \\
90 \\
95 \\
\end{array}$ & $\begin{array}{r}90 \\
101 \\
99 \\
104 \\
78 \\
96 \\
105 \\
82 \\
\\
94 \\
\end{array}$ & $\begin{array}{r}80 \\
102 \\
92 \\
104 \\
73 \\
108 \\
96 \\
-79 \\
76 \\
85\end{array}$ & $\begin{array}{r}84 \\
101 \\
86 \\
107 \\
74 \\
109 \\
101 \\
70 \\
86 \\
98 \\
82 \\
\end{array}$ & $\begin{array}{r}81 \\
95 \\
95 \\
101 \\
71 \\
109 \\
110 \\
77 \\
\\
92 \\
\end{array}$ & $\begin{array}{r}75 \\
80 \\
91 \\
104 \\
73 \\
110 \\
90 \\
76 \\
87 \\
\end{array}$ & $\begin{array}{r}92 \\
88 \\
97 \\
100 \\
71 \\
108 \\
92 \\
-\quad 85 \\
81 \\
90 \\
\end{array}$ & $\begin{array}{r}75 \\
99 \\
90 \\
98 \\
91 \\
111 \\
90 \\
75 \\
87 \\
101 \\
92 \\
\end{array}$ & $\begin{array}{r}85 \\
82 \\
97 \\
107 \\
89 \\
102 \\
95 \\
83 \\
\\
92 \\
\end{array}$ & $\begin{array}{r}70 \\
70 \\
91 \\
102 \\
89 \\
108 \\
91 \\
86 \\
88 \\
\end{array}$ \\
\hline
\end{tabular}

${ }^{*} \mathrm{E}=$ Early in the exposure, first half hour average values.

$\dagger \mathrm{L}=$ Late in the exposure, 1.5 to $2.5 \mathrm{~h}$, average values.

MMFR = Maximum midexpiratory flow rate.

- Not determined.

* Greater than $30 \%$ change.

$\dagger 1 \mathrm{ppm} \mathrm{SO}_{2}$.

plus carbon dust. The results for these exposures are shown separately in table 3 and indicate minimal changes in pulmonary function.

Subject 9 also showed a striking response to 5 ppm $\mathrm{SO}_{2}$. After only 15 minutes of exposure to 5 ppm $\mathrm{SO}_{2}$ at rest, the decrease in $\mathrm{FEV}$, was $42 \%$ and the $\mathrm{SO}_{2}$ was shut off for four minutes. The concentration was then re-established at $1 \mathrm{ppm} \mathrm{SO}$ which was tolerated well and the FEV, began to return to normal, showing a decrease from baseline of $27 \%$ after the first exercise period (35 minutes) and 17\% (40 minutes) after the second. At this time (40 minutes) the concentration of $\mathrm{SO}_{2}$ was raised to 2 $\mathrm{ppm}$ and the $\mathrm{FEV}_{1}$ fell again showing a $48 \%$ decrease from baseline after the third exercise period (45 minutes). The concentration was then returned to $1 \mathrm{ppm} \mathrm{SO}$ and the $\mathrm{FEV}_{1}$ began to improve again, returning to control levels at the end of the exposure (150 minutes).

\section{CLEARANCE}

The figure shows the clearance curves for the nine individuals in the study. The retention of the test aerosol at two hours, expressed as a percentage of the initial lung burden, was used to assess if there had been significant changes during pollutant exposures (table 4). From table 4 it can be seen that the results were mixed with both speeding and slowing of clearance. As may be seen in the figure, subject 8 , an asthmatic, showed a complete cessation of clearance after 30 minutes exposure to $1 \mathrm{ppm} \mathrm{SO}_{2}$ plus carbon dust. It was not possible to expose the other asthmatic to the combination of pollutants. Neither asthmatic showed changes in clearance after exposure to $5 \mathrm{ppm} \mathrm{SO}_{2}$ when treated with a bronchodilator. Subject 7 showed a considerable slowing
Table 4 Retention of radioaerosol two hours after beginning of exposure

\begin{tabular}{|c|c|c|c|}
\hline Subject & Placebo & $\mathrm{SO}_{2}$ & $\begin{array}{l}\mathrm{SO}_{2} \\
\text { dust }\end{array}$ \\
\hline $\begin{array}{l}1 \\
2 \\
3 \\
4 \\
5 \\
6 \\
7 \\
8 \\
9 \\
\text { Mean } \pm \text { SD }\end{array}$ & $\begin{array}{l}61 \cdot 0 \\
29.5 \\
75 \cdot 0 \\
43.0 \\
58 \cdot 0 \\
51 \cdot 5 \\
50.5 \\
22 \cdot 5 \\
19.5 \\
49 \pm 17 \dagger\end{array}$ & $\begin{array}{l}60.0 \\
16 \cdot 0 \\
80.5 \\
53 \cdot 0 \\
50.0 \\
51 \cdot 0 \\
50.0 \\
19 \cdot 0^{*} \\
14 \cdot 0^{*} \\
47 \pm 21 \dagger\end{array}$ & $\begin{array}{l}35 \cdot 0 \\
23 \cdot 0 \\
68 \cdot 0 \\
39 \cdot 0 \\
41 \cdot 5 \\
52 \cdot 5 \\
62 \cdot 0 \\
45 \cdot 0^{*} \\
46 \pm 15 \dagger\end{array}$ \\
\hline
\end{tabular}

${ }^{*} 1 \mathrm{ppm} \mathrm{SO} \mathrm{S}_{2}$.

†Excluding subject 9.

Table 5 Histamine bronchial reactivity

\begin{tabular}{|c|c|c|c|}
\hline \multirow{2}{*}{$\begin{array}{l}\text { Threshold } \\
\text { concentration } \\
\text { Subject }(\mathrm{mg} / \mathrm{ml})\end{array}$} & \multicolumn{3}{|c|}{ Percentage fall in $F E V_{1}$} \\
\hline & Placebo & $\mathrm{SO}_{2}$ & $\underset{\text { dust }}{\mathrm{SO}_{2}}+$ carbon \\
\hline $\begin{array}{ll}1 & 4 \\
2 & 1 \\
3 & 1 \\
4 & 4 \\
5 & 1 \\
6 & 1 \\
7 & 8 \\
8 & 0 \cdot 5 \\
9 & 0 \cdot 25 \\
\text { Mean }+ & \text { SD } \\
\text { p value* }\end{array}$ & $\begin{array}{r}23 \cdot 0 \\
8 \cdot 3 \\
10.7 \\
37 \cdot 0 \\
28 \cdot 4 \\
20.5 \\
9.2 \\
16.7 \\
31 \cdot 0 \\
19 \pm 10 \dagger\end{array}$ & $\begin{array}{l}23 \cdot 9 \\
13.9 \\
21 \cdot 0 \\
32 \cdot 0 \\
31 \cdot 7 \\
35 \cdot 6 \\
14 \cdot 3 \\
34 \cdot 0 \\
26 \pm 9 \dagger \\
<0.05\end{array}$ & $\begin{array}{r}40 \cdot 4 \\
6 \cdot 9 \\
10 \cdot 7 \\
29 \cdot 8 \\
21 \cdot 6 \\
30 \cdot 1 \\
8 \cdot 4 \\
47 \cdot 7 \\
24 \pm 15 \dagger \\
0.5\end{array}$ \\
\hline
\end{tabular}

*Exposure measurements compared with control using paired tests.

†Excluding subject 9 . 
(1)
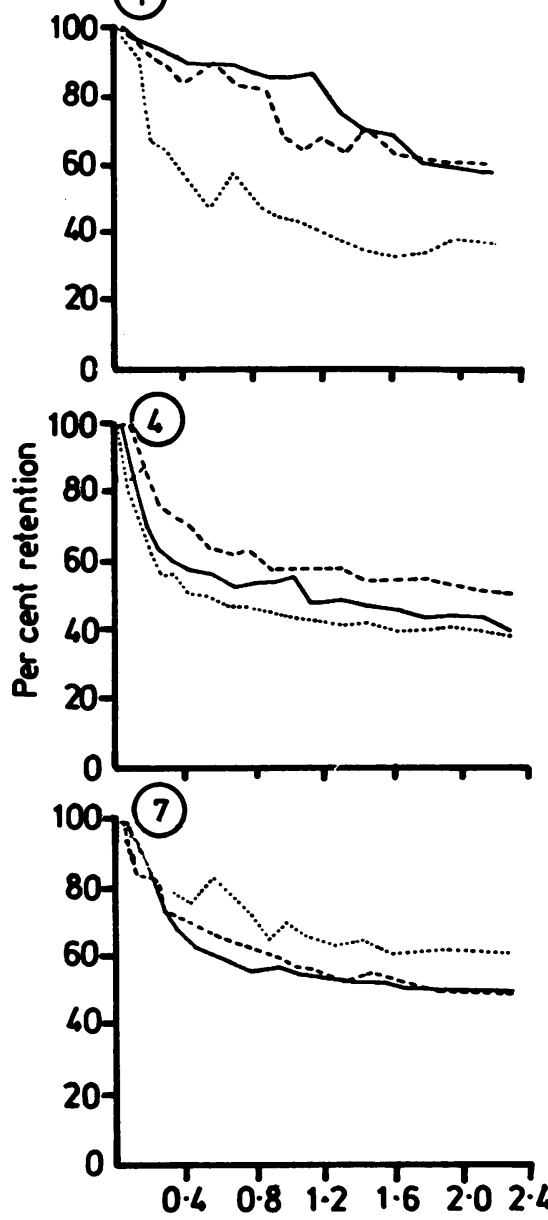

(2)
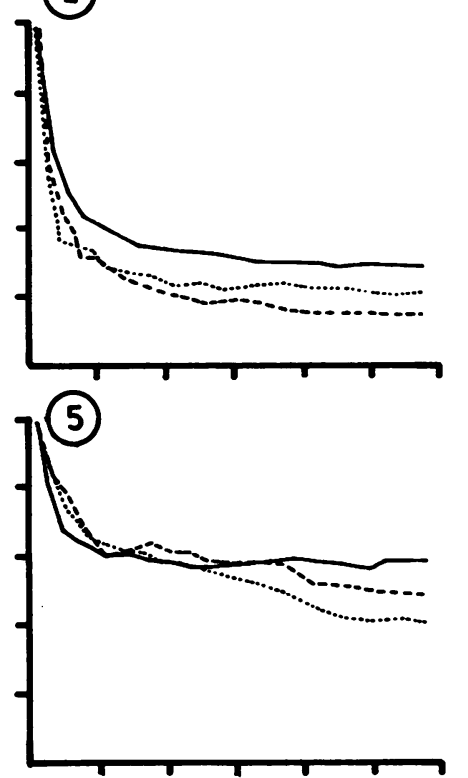

(8)

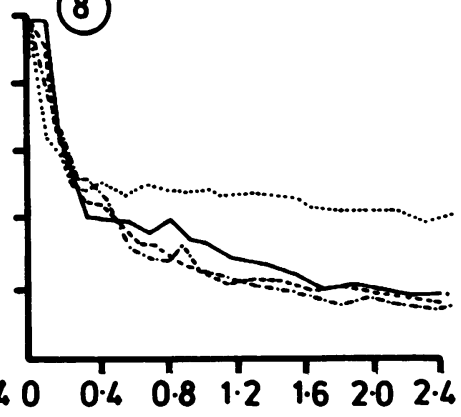

(3)
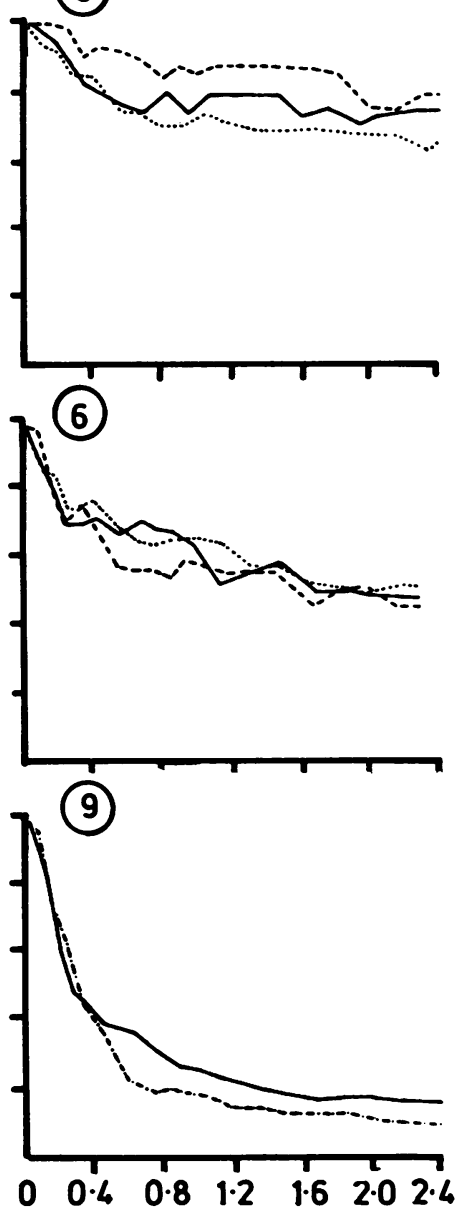

Time (h)

Lung retention of activity expressed as a percentage of initial lung burden plotted as a function of time. Retention curves are shown for control exposures (-), exposures to 5 ppm SO $\mathrm{SO}_{2}(---)$, and 5 ppm SO $\mathrm{S}_{2}$ plus carbon dust (…). Retention curves for subjects 7-9 (group 3). Subject 8 was exposed to 1 ppm $\mathrm{SO}_{2}(---)$ and 1 ppm SO $\mathrm{SO}_{2}+$ carbon dust $(\cdot \cdots)$ for entire period and 5 ppm SO $\mathrm{SO}_{2}(---)$ for 0.5 hour. Subject 9 was exposed to $1 \mathrm{ppm} \mathrm{SO}_{2}\left(--_{-}\right)$for most of exposure period (see text).

in clearance on exposure to $5 \mathrm{ppm} \mathrm{SO}_{2}$ plus carbon dust.

\section{BRONCHIAL REACTIVITY}

Table 5 shows the threshold concentrations and percentage decrease in $\mathrm{FEV}_{1}$ when these concentrations were administered after exposure. They indicate that the greatest change occurred on exposure to $\mathrm{SO}_{2}$, when virtually all subjects had a much greater fall in FEV, with the same histamine concentration compared with the exposures to placebos. The one exception was subject 8 , who showed a much greater sensitivity to $\mathrm{SO}_{2}$ plus carbon dust than to $\mathrm{SO}_{2}$ alone. Paired $t$ tests were used to analyse the data for significant changes. The $p$ values at the bottom of the table indicate that changes were significant during exposure to $\mathrm{SO}_{2}(\mathrm{p}<0.05)$ but were not significant during exposure to $\mathrm{SO}_{2}$ plus carbon dust $(p<0.5)$.

SUBJECTIVE IMPRESSIONS

Virtually all the subjects appeared to find the expos- 
ures to $\mathrm{SO}_{2}$ more irritating than did the young normal subjects of earlier experiments. ${ }^{2}$ Most subjects stated that the exposure to $\mathrm{SO}_{2}$ plus carbon dust was more unpleasant and irritating than to $\mathrm{SO}_{2}$ alone. During exposure, some subjects coughed occasionally but not to a degree that would be expected to influence the clearance results.

\section{Discussion}

The data presented here describe the effects of exposure to $\mathrm{SO}_{2}$ or $\mathrm{SO}_{2}$ plus carbon dust in individuals who had some respiratory problems at work. Most other data relate to healthy volunteers or to animal exposures. Previous studies in this laboratory ${ }^{2}$ have shown an increase in clearance during the acute exposure of young, healthy, nonsmoking subjects to $\mathrm{SO}_{2}$. Camner et al have shown that exposure to carbon dust also increases bronchial clearance ${ }^{3}$ and so it would seem likely that exposure to $\mathrm{SO}_{2}$ plus carbon dust in healthy subjects would increase clearance. In the individuals with the best pulmonary function (subjects $1,2,3$ ) there was a trend towards faster clearance after exposure both to $\mathrm{SO}_{2}$ and to $\mathrm{SO}_{2}$ plus carbon dust. Subject 3 showed slower clearance in response to $\mathrm{SO}_{2}$ but the result was within the experimental variation. We have suggested previously that increased clearance may be a response to increased mucus production, ${ }^{2}$ resulting from the stimulation of vagal receptors in the upper airway.

Increases in clearance may or may not be beneficial, but decreases in clearance in response to an inhalation insult would probably be detrimental. Impairment of clearance may also allow mucus to accumulate and increase the risk of obstructing airways. In this regard it is noteworthy that two subjects showed a pronounced decrease in clearance during exposure to $\mathrm{SO}_{2}$ as did three during exposure to $\mathrm{SO}_{2}$ plus carbon dust. (A pronounced change is one that is greater than the $7 \%$ standard deviation found previously for repeat studies. ') Whether these observations represent an indication of heterogeneous responses to these agents or greater variability in the clearance measurements of these workers than of young healthy subjects cannot be determined with absolute certainty.

Yeates has reported less reproducibility in patients with chronic bronchitis than in normal subjects. ${ }^{8}$ Our subjects were in reasonably good health in that they were all still working and had only limited debilitation and there was no significant difference in clearance from previous control data obtained in normal subjects ${ }^{2}$ by contrast with the observation of Camner et al of slower clearance in chronic bronchitis.' Initial deposition and clearance in the first half hour before pollutant exposures were started were similar for each subject. These facts suggest that our subjects may not have as great a variability as those with chronic bronchitis, but responses could be more varied than observed in a population of normal healthy subjects.

Subjects 8 and 9 , the asthmatics, showed fast clearance with retentions of $22.5 \%$ and $19.5 \%$, respectively, after two hours, which is faster than that seen in any of the normal subjects in previous studies. ${ }^{2}$ This may be a chance occurrence but it finds a parallel in the data of Wanner et al ${ }^{10}$ who sensitised dogs to ascaris antigen and showed that the tracheal mucous velocity was $8.6 \pm 1.8 \mathrm{~mm} /$ minute compared with $4.8 \pm 1.0$ for controls. Thus in this animal model and in our two asthmatic subjects baseline mucous velocity was faster in the asthmatics than in normal controls.

The response of the two asthmatics to $\mathrm{SO}_{2}$ was striking and both showed such pronounced reductions in $\mathrm{FEV}_{1}(42 \%$ and $60 \%$, respectively) on exposure to $5 \mathrm{ppm} \mathrm{SO}_{2}$ that the exposures had to be terminated or reduced. The reason that no impairment in clearance was seen at exposures to $5 \mathrm{ppm}$ $\mathrm{SO}_{2}$ was probably because a bronchodilator, which can increase clearance," was administered to subject 8 . The exposure level was reduced dramatically for subject 9, perhaps reducing clearance response below a detectable level. Obviously, the generally accepted TLV levels are much too high for these individuals.

Our results are in agreement with those of Sheppard $e t a l^{12}$ and Jaeger $e t a l^{13}$ who observed that asthmatics showed a greater response to $\mathrm{SO}_{2}$ than normal subjects. It is also interesting that one of the asthmatics (subject 8 ) showed a complete cessation of clearance after 30 minutes exposure to $1 \mathrm{ppm} \mathrm{SO}{ }_{2}$ plus carbon dust; this has not been observed in previous studies of normal subjects. Data could not be obtained for the other asthmatic under these conditions. Even from these limited data it is apparent that asthmatics are particularly sensitive to such irritants.

There were no statistically significant changes in any of the pulmonary function measurements for the set of subjects as a whole, and no changes which were seen after exposures to pollutant occurred only in the two asthmatics. They showed appreciable changes in $\mathrm{FEV}_{1}, \mathrm{FEF}_{75-25}$, and in $\dot{\mathrm{V}}_{50}$ and $\dot{\mathrm{V}}_{25}$. In the other subjects $\dot{V}_{25}$ appeared to be the most sensitive indicator of changes possibly suggesting some small airway effects late in the exposures to $\mathrm{SO}_{2}$ plus carbon dust (table 3 ).

Our finding of increased bronchial reactivity on exposure to $\mathrm{SO}_{2}$ agrees well with the data which Ulmer obtained in dogs..$^{14}$ is $\mathrm{We}$ are unable to 
explain why bronchial reactivity was closer to control values for exposures to $\mathrm{SO}_{2}$ plus carbon dust than for $\mathrm{SO}_{2}$ alone. Possibly some $\mathrm{SO}_{2}$ was adsorbed on to the carbon dust ${ }^{16}$ and deposited more deeply into the lung where there are fewer irritant receptors. ${ }^{17}$ This might produce a reduced stimulation of the cholinergic pathways and so might not affect bronchial reaction as much as $\mathrm{SO}_{2}$ alone. Approximately $20 \%$ of the $\mathrm{SO}_{2}$ was in fact absorbed on to the carbon in the presence of the dust, since the flow of $\mathrm{SO}_{2}$ into the chamber had to be increased by this amount to maintain a $5 \mathrm{ppm} \mathrm{SO}_{2}$ concentration in the air.

The subjects we used did not represent a homogeneous group and so it is difficult to generalise from the data. Some subjects appeared to show impairments but, overall, the results indicate that only individuals with a degree of respiratory disease have more variable responses than healthy subjects.

It is clear that asthmatics appear to be at particular risk and their exposure to irritant gases and particles should be limited. Although complete data were only obtained in one asthmatic subject, his striking response indicates that mucociliary clearance may be severely impaired when asthmatics are exposed to relatively low concentrations of $\mathrm{SO}_{2}$.

We thank colleagues in the respiratory unit at St Joseph's Hospital and the cardiorespiratory unit at McMaster University for useful comment and discussion.

Requests for reprints to: Dr R K Wolff, Inhalation Toxicology Research Institute, PO Box 5890, Albuquerque, NM 87185, USA.

Supported by the Canadian Medical Research Council, grant No MA-4265.

\section{References}

' Wolff RK, Dolovich M, Rossman CM, Newhouse MT. Sulfur dioxide and tracheobronchial clearance in man. Arch Environ Health 1975;30:521-7.

2 Wolff RK, Dolovich M, Obminski G, Newhouse MT. Effect of TLV levels of $\mathrm{SO}_{2}$ and $\mathrm{H}_{2} \mathrm{SO}_{4}$ on bronchial clearance in man. Arch Environ Health 1978;33:24-31.

${ }^{3}$ Camner P, Helstrom PA, Philipson K. Carbon dust and mucociliary transport. Arch Environ Health 1973;26:294b-6.

${ }^{4}$ Frank NR, Amdur MO, Worcester J, Whittenberger JL. Effects of acute controlled exposure to $\mathrm{SO}_{2}$ on respiratory mechanics in healthy male adults. J Appl Physiol 1962;17:252-8.

s Sanchis J, Dolovich M, Chalmers R, Newhouse MT. Quantitation of regional aerosol deposition and clearance in the normal human lung. J Appl Physiol 1972;33:757-62.

- Games PA. An improved t-table for simultaneous control on $\mathrm{g}$ contrasts. Journal of the American Statistical Association 1977;72:531-4.

7 Cockcroft DW, Killian DN, Mellon A, Hargreave FE. Protective effect of drugs on histamine-induced asthma. Thorax 1977;32:429-37.

8 Yeates DB, Cohen VR, Davis AL, et al. A study of the relationship between the clinical characteristics and bronchial clearance and deposition patterns in patients with chronic bronchitis. Am Rev Respir Dis 1977;115:390 suppl.

9 Camner P, Mossberg B, Philipson K. Tracheobronchial clearance and chronic obstructive lung disease. Scandinavian Journal of Respiratory Disease 1973;54:272-81.

${ }^{10}$ Wanner A, Zarzecki S, Hirsch J, Epstein S. Tracheal mucous transport in experimental canine asthma. J Appl Physiol 1973;39:950-7.

" Camner P, Strandberg K, Philipson K. Increased mucociliary transport by adrenergic stimulation. Arch Env Health 1976;29: $220-4$.

${ }^{2}$ Sheppard D, Wong WS, Uehara CF, Nadel JA, Boushey HA Lower threshold and greater bronchomotor responsiveness of asthmatic subjects to sulfur dioxide. Am Rev Respir Dis 1980; 122:873-8.

13 Jaeger MJ, Tribble D, Wittig HJ. Effect of $0.5 \mathrm{ppm}$ sulfur dioxide on the respiratory function of normal and asthmatic subjects. Lung 1979;156:119-27.

14 Islam MS, Vastag E, Ulmer WT. Effect of noxious stimulants on bronchial reactivity. Bull Physiopath Resp 1972;8:509-18.

is Ulmer WT. Inhalative noxen. Schwefeldioxyd Pneumonologie 1974; 150:83-96.

${ }^{10}$ Boren HG. Carbon as a carrier mechanism for irritant gases. Arch Environ Health 1964;8:119-24.

17 Widdicombe JF. Physiological responses to inhalations of cigarette smoke and other irritant gases and aerosols. Societa Italiana Di Biologice Sperimentale-Bolletino 1973;49:19-38. 